\title{
The Impact of the New National Senior High School English Curriculum on Collaboration Between Japanese Teachers and Native Speakers
}

\section{Gregory Paul Glasgow General Center for Education, Meikai University, Urayasu Campus}

In this paper I discuss the impact of the Ministry of Education's new national senior high school Course of Study for Foreign Languages on collaboration between Japanese teachers of English and native speakers of English. In consideration of the new curriculum's request that classes be conducted in English and its reorganization of all English subjects, I draw upon frameworks in language-in-education policy and planning (Kaplan \& Baldauf, 2003; Liddicoat, 2004) and highlight potential issues concerning its implementation at the local level.

本研究では文部科学省の新しい外国語学習のための指導要領が日本人教師と英語母語話 者との間の連携に与える影響について議論する。新しいカリキュラムの全体目標と全英語科目 の再構成に鑑み、本研究では教育における言語政策・計画の枠組み(Kaplan \& Baldauf, 2003; Liddicoat, 2004)から現場レベルで害施する際に起こりうる問題を明らかにする。

JALT Journal, Vol. 35, No. 2, November 2013 


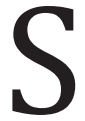

enior high school English departments around Japan are enacting the new national Course of Study for Foreign Languages (hereinafter, Course of Study) released by the Ministry of Education, Culture, Sports, Science and Technology (MEXT). The new curriculum has received an increased amount of attention in the literature on English education in Japan (Glasgow, 2012; Tahira, 2012; Underwood, 2012; Yamada \& Hristokova, 2011). As evidenced by new subject names such as English Communication, English Expression, and English Conversation, MEXT continues to signal the need for classes to integrate the four macro-skills of listening, speaking, reading, and writing, and to focus on communicative proficiency. Kikuchi and Browne (2009) stated that the revision of subjects "seems likely to increase the pressure on teachers at all levels to help develop students' communicative ability" (p. 189).

The new curriculum has eliminated the 1st- and 2nd-year Oral Communication subjects, in which Japanese teachers of English (JTEs) collaborated with native speakers of English who served as assistant language teachers (ALTs). These classes, along with the introduction of the Japan Exchange and Teaching (JET) Programme in 1987, were intended to increase intercultural exchange as well as enhance students' spoken proficiency; however, several authors have indicated problems in their implementation (Hiramatsu, 2004; Kachi \& Lee, 2001; Mahoney, 2004; McConnell, 2000; Tajino \& Walker, 1998). Furthermore, the proliferation of non-JET agencies that supply ALTs to prefectural Boards of Education has led to problems surrounding their employment (Hashimoto, 2013). Hence, a critical question is to be posed: in the new Course of Study, how will JTEs and ALTs work together equitably and collaboratively to fulfil its objectives?

In this paper, I explore the impact of the new Course of Study on JTEs who work with native speakers serving as teachers and assistants in the Japanese school system. I will summarize concepts in nonnative speaking (NNS) and native speaking (NS) English teacher studies that have accounted for the distinctions in NS-NNS teaching behaviour. Then, drawing upon Liddicoat's (2004) framework highlighting the role of teaching methodology in language-in-education policy, I will explore the new curriculum in terms of curriculum planning, teaching materials, methodology, and assessment. It is envisioned that this paper will provide teachers with the opportunity to critically reflect on the new curriculum and consider how its goals can be realized in a contextually relevant manner at the local level. 


\section{NNS and NS Teacher Collaboration and the New Course of Study}

NNS and NS English teachers around the world have the potential to collectively and positively influence student learning. However, each group possesses its own challenges with respect to issues concerning professional identity and legitimacy. Medgyes (1999), in his seminal work on NS and NNS English teachers, determined that irrespective of differences in teaching approaches and language proficiency, both can be equally good teachers on their own terms. However, NNS English teachers are affected by discriminatory hiring practices and perceived weaknesses with respect to language proficiency and teaching competence (Braine, 2010), exacerbated by the pervasive nature of the native speaker fallacy (Phillipson, 1992) as a result of which NS English teachers benefit from a more privileged status. Recently, however, attention has shifted to how NS English teachers have been affected by restrictive policies and ambiguities in their professional roles (Breckenridge \& Erling, 2011; Houghton \& Rivers, 2013). Therefore, the self-images of both NS and NNS teachers will need to be improved by supportive policies in language education.

The JET Programme was a major initiative put in place to foster NS-NNS English teacher collaboration. I reflect on its implementation to demonstrate how the roles of ALTs and JTEs have been positioned in terms of the new Course of Study. The literature on the JET Programme and team-teaching (TT) in Japan can be found in the form of books (Brumby \& Wada, 1992; McConnell, 2000; Wada \& Cominos, 1994), doctoral dissertations (Hiramatsu, 2004; Miyazato, 2006), and a significant number of local and international journal articles (Crooks, 2001; Gorsuch, 2002; Kachi \& Lee, 2001; Mahoney, 2004; Tajino \& Walker, 1998). Two major resources for the JET Programme, the MEXT Handbook for Team Teaching (2002) and the Council of Local Authorities for International Relations (CLAIR) ALT Handbook (2012), have stated that team teaching requires good cooperation between ALTs and JTEs so that they can encourage students to use English for real communicative purposes inside the classroom.

However, the implementation of TT is difficult at the local level due to what Carless (2006) has referred to as logistical factors, pedagogical factors, and interpersonal factors. These provide a general understanding of challenges faced in TT. First, with respect to logistical factors in Japan, Gorsuch (2002) pointed out that there is division of labor between ALT and JTE classes, in which reading and writing classes serve as the domain of JTEs, whereas ALTs tend to be commissioned for conversation classes. This division can also be accentuated by the lack of frequency with which 
ALTs meet the students (Browne \& Evans, 1994; McConnell, 2000). When ALTs and students do meet, students may infer that the TT class is a one-off performance. Carless (2006) noted that such classes are often insufficiently integrated into the wider curriculum. With respect to pedagogical factors, Miyazato (2006) examined issues of power sharing in TT classrooms and concluded that ALTs may have linguistic power in the classroom, but are politically weaker due to lack of knowledge of Japanese as well as of the Japanese education system. Moreover, Kachi and Lee (2001) reported that both JTEs and ALTs receive little preparation to carry out their jobs in TT. Finally, in term of interpersonal factors, Voci-Reed (1994) noted challenges in cultural communication styles.

Taking into consideration these factors, the question that arises is how these lingering problems will be addressed in the new curriculum. Section 8, Article 4, 2 (4) of the new Course of Study (MEXT, 2011a) states that "team-teaching classes conducted in cooperation with native speakers, etc. should be carried out in order to develop students' communication abilities" (p. 7, italics mine). The explanatory guidebook for the new curriculum (MEXT, 2010), entirely in Japanese, refers to the attributes of native speakers as instrumental in increasing communication skills without any further explanation of what exactly those attributes are. Currently, the CLAIR ALT Handbook does not mention the new senior high school curriculum, and uploaded materials to provide new ALTs with support (JET, 2010) are not explicitly connected to it. However, a report from the Association of JET Opinion Exchange Meeting in Winter 2012 stated that MEXT is creating a revised handbook for team teaching and e-learning platform that will most likely be released at a later date (AJET, 2012).

To summarize, though many studies have provided suggestions for improvement, the system has not changed. Moreover, the Japanese government has been reviewing ministerial programmes for their efficacy, with the JET Programme being criticized for not meeting regional demands (Hashimoto, 2013). According to Mie (2013), a draft of the midterm report of the Liberal Democratic Party's Economic Revitalization Unit announced plans to increase the number of JET teachers to 10,000 in about 3 years. Although such an initiative sounds impressive, questions still remain regarding future ALT-JTE collaboration in the new curriculum. 


\section{Language-in-Education Policy Goals and the New National Curriculum}

The revisions to the English curriculum can be viewed as language-ineducation policy decisions (Kaplan \& Baldauf, 2003). These decisions are made in terms of the following subgoals: (a) curriculum policy (the goal and content of the curriculum), (b) methods and materials policy (the methodology and teaching materials used), (c) evaluation or assessment policy (the way in which the curriculum or the learners are evaluated), (d) personnel policy (the teachers hired to fulfil the goals), (e) access policy (when the policy is to be introduced), and (f) resource policy (time and financial considerations). In order to further account for the role of teaching method, Liddicoat (2004) cited methods and materials separately as two of four policy goals, along with curriculum and assessment, as critical in investigating how language-in-education policy affects language teaching methodology. The new Course of Study, with its call for classes to be taught in English, is suggesting a change in method. This can be detected in an excerpt from Chapter 3 of the explanatory guidebook of the new Course of Study (MEXT, 2010) that states that teaching should not be "centred on the explanation of points, simple translation or instruction in grammar, but instead focus on providing students with exposure to English and opportunities to communicate in English" (p. 43, English translation mine, italics mine).

As language teaching methods policy can influence and be influenced by materials, curriculum, and assessment policy, I draw upon this framework to explore the impact of the new Course of Study on JTEs and native speakers at the institutional and classroom level.

\section{Curriculum Policy: What Are the Roles of Japanese Teachers and Native Speakers?}

In the new curriculum, the new subject English Communication (Basic 1, 2 , and 3) focuses on the integration of the macro-skills of speaking, listening, reading, and writing. The emphasis of English Communication is on the four macro-skills through activities such as speed-reading and class discussions (MEXT, 2010). Elective subjects, English Expression 1 and 2, develop speaking and writing skills, and students learn presentation methods and to write appropriately for a situation (MEXT, 2011a). The final new subject, English Conversation, is an elective created to enhance speaking and listening skills (MEXT, 2010; 2011a). The new curriculum stresses the development of students' abilities to accurately understand and convey information and ideas 
(MEXT, 2011a) and suggests that students be given more chances to use English in all English subjects.

With respect to JTEs, there is the implication that establishing English as the language of instruction will render the ALT role superfluous, as the ALT has been viewed as a key catalyst for the development of students' use of L2 communicative skills (Wada, 1994). At the same time, the new curriculum does state that although contemporary standard English should be used in principle (MEXT, 2011a), consideration should be given to raising students' awareness of other varieties of English. McKenzie (2013) has noted that the US and UK standard models have been historically preferred in Japan, but he added that researchers have argued for a de-Anglo-Americanized pedagogical model. The fact that JTEs will be expected to teach classes in English brings up the issue of whether or not Japanese-accented English should represent the contemporary standard variety. Should this be the case, many JTEs may need support in changing their perceptions towards their accents, as it has been pointed out by Miura (2010) that the JTEs who felt most anxious about teaching in English were not confident in their pronunciation. Furthermore, the Course of Study explanatory guidebook (MEXT, 2010) refers to ALTs in the English Conversation class only. In the explanations of the English Expression and English Communication classes, ALTs are not mentioned, raising questions as to how their roles will change after oral communication classes have been eliminated and suggesting that the knowledge base of the ALT will need to be adjusted to conduct class in a more integrated manner. Therefore, the preparedness of ALTs and JTEs is of concern here.

\section{Methods Policy: Will English Actually Be Taught in English by all Teachers?}

The methods policy requests that classes be conducted in English with some Japanese permitted for grammatical explanations (MEXT, 2010; 2011a). However, the wording "classes conducted in English" has apparently confused some JTEs, who have mistakenly believed that they have to conduct English-only classes (Miura, 2010). Although the English version of the Course of Study (MEXT, 2011a) says English classes should be conducted in English and that "consideration should be given to use English in accordance with the students' level of comprehension" (p. 7), the explanatory guidebook for the Course of Study in Japanese asserts the following: 
These guidelines stress the importance of conducting classes in English because it provides many opportunities for students to gain exposure to English and create actual communication situations in the classroom. This is not to say that the entirety of all classes must be conducted in English. Japanese can be used as needed in class as well, provided the lessons are focused mainly on language activities (MEXT, 2010, p. 44, English translation mine, emphasis mine).

The information provided by the explanatory guidebook, with its mention of Japanese, can be considered as what Tollefson and Tsui (2004) have referred to as exit clauses and qualified statements in policies that seek a change in the language of instruction. Statements such as "Japanese can be used as needed in class" and "in accordance with the students' level of comprehension" serve as examples of noncommittal language. Furthermore, the issue of using the L1 in a second or foreign language classroom remains a sensitive one for NNS teachers even though several studies in foreign language, bilingual education, and English-medium classrooms have recognized its facilitative role (Hall \& Cook, 2012; Turnbull \& Dailey-O'Cain, 2009). More research needs to be conducted on whether NS teachers are any more effective when using their own L1. In Hong Kong, Luk and Lin (2006) found that being an NS English teacher did not necessarily guarantee successful classroom management and learner acquisition, nor does being an NS guarantee superior writing skills (Andrews, 2007).

Methods policy will not only be challenging for JTEs in solo-taught classrooms but also for TT classrooms. Though team-teachers can indeed coordinate language use with judicious L1 support (Carless \& Walker, 2006), cases exist where JTEs serve as interpreters for ALTs (Tajino \& Walker, 1998), translating ALT instructions whether or not students need L1 clarification. Drawing on terminology from Martin (2005), I refer to such interpreting as a "safe practice" (p. 89); I suggest that Japanese is used in such cases to relieve students from the potential anxiety of negotiating meaning in the L2. Other contextual factors such as class sizes and the textbook are also challenging. It is difficult to foresee any changes in language practices if English departments do not carefully consider a "clearly articulated approach or set of principles and consistently applied pedagogical tools" (Levine, 2011, p. $127)$ to address code choice in the classroom. 


\section{Materials Policy: Will the Textbooks Reflect the Goals of the New Curriculum?}

Textbooks for the subjects to be taught in 1st-year senior high school classes have already been approved and published. Textbook writers, however, are often influenced by commercial factors, which can cause "slippage" between the intended curriculum and its resourced curriculum, or textbooks, as Adam and Davison (2003, p. 32) found in their study on the implementation of the task-based approach in Hong Kong primary schools. McGroarty and Taguchi (2005), in a study on textbooks for the oral communication class in the 1994 Course of Study, found that the activities in the textbooks did not develop pragmatic competence and had a limited range of exercise types to promote spontaneous open-ended communication. This corroborates Cohen and Ishihara's (2013) concerns that "textbooks do not provide sufficient interactive exercises for practicing the introduced forms and discussing sociocultural norms of the target language" (p. 119).

The issue of materials is a significant one for ALTs and JTEs, with ALTs tending to rely on materials that focus on speaking and listening, and JTEs using materials that focus more on grammatical competence, a common practice noted by Smiley and Masui (2008). These practices further reinforce the ALT-JTE role divisions. Therefore, in order for the more ambitious objectives of the new curriculum to be realized, schools will still have to critically assess textbooks to determine which ones best meet the objectives and what to do if they fall short. Kennedy and Tomlinson (2013) also pointed out that "policies might change but examinations tend to remain the same (and examinations tend to determine what published materials do)" (p. 265).

\section{Assessment Policy: Will It Change to Align With the New Curriculum?}

The National Center Test for University Admissions, as well as secondstage university examinations, remain as the current assessment policy. In addition, Prime Minister Shinzo Abe has also been weighing whether or not to make the TOEFL test a key resource for English language assessment for university entrance (Hongo, 2013). This recent move coincides with the Five Proposals and Specific Measures for Developing Proficiency in English for International Communication (MEXT, 2011b), in which concern exists as to how to ensure that the four skills are "tested at proper balance" (p. 12). The national university entrance exams continue to operate as a "de facto language policy" (Menken, 2008; Shohamy, 2006) that has washback 
not only on classroom practices but also on language use. Menken (2008) found similar issues in a study on English language learners in New York City senior high schools, where the high stakes Regents graduation exam has significantly influenced teachers' language choices and curriculum decisions. With the entrance examination firmly entrenched as the assessment policy, the potential for the continuation of the status quo remains.

There are issues that need clarification with respect to the impact of the assessment policy, or national university entrance exams, on teachers' practices. In his study of JTE beliefs and intentions to implement the new national curriculum, Underwood (2012) stated that "for the majority of teachers a reform-oriented approach is also seen to be at the expense of grammatical accuracy and knowledge of grammar, which was frequently reported as important in preparing for [university entrance exams]" (p. 919). One of his participants reported "having to use-against her better judgment-the Oral Communication 1 class (grade 10) entirely for grammar work" (p. 917) due to perceived entrance examination pressures. Sakui (2004), in her study on JTE implementation of communicative practices, noted that JTEs "cannot ignore the demand to prepare students for entrance examinations" (p. 159) and found that students perceived communicative approaches as not serious study. Hence, equipping ALTs and JTEs with the knowledge to bridge the perceived gulf between "entrance examination English" and "communicative English" remains a major challenge, as the new Course of Study has explicitly stated that "grammar instruction should be given as a means to support communication through effective linkage with language activities" (MEXT, 2011a, p. 7)

\section{Conclusions}

This paper has outlined issues in the implementation of the new Course of Study as it pertains to collaboration between JTEs and ALTs in Japanese senior high schools. Though theoretical perspectives on NS-NNS English teachers have shown that their strengths and weaknesses complement each other, structural challenges in terms of curriculum, methods, materials, and assessment policy subgoals raise serious questions as to how the new curriculum will translate into effective pedagogical practice. It has been shown that the curriculum policy has not clearly articulated the roles of ALTs and JTEs in terms of the intended pedagogical model and teaching expectations. The practice of conducting classes in English as a methods policy has yet to be truly accepted in the team teaching classroom, where teachers have resorted to ad hoc language practices. The materials policies in past cur- 
ricula have shown inconsistencies between the intended curriculum and the published textbooks that are bound to affect ALT-JTE teaching practice. Finally, the assessment policy remains and will continue to have an impact as a de facto language policy that affects language of instruction, methodology, and curriculum priorities.

According to Garcia \& Menken (2010), "good language educators do not blindly follow a prescribed text or march to an imposed language education policy" (p. 258). Therefore, it will be incumbent upon both groups of teachers in their respective departments to negotiate these challenges and to develop localized solutions that suit their contexts.

\section{Acknowledgements}

I would like to thank Dr. Jeremy Breaden for his assistance with the English translation of portions of the new Course of Study explanatory guidebook.

Gregory Paul Glasgow is an assistant professor at Meikai University. His research interests are language-in-education policy and planning, English as an International Language (EIL), and multilingualism in language education.

\section{References}

Adamson, B., \& Davison, C. (2003). Innovation in English language teaching in Hong Kong primary schools: One step forward, two steps sideways. Prospect, 18(1), 27-41.

AJET. (2012). Winter 2012 OE: Utilization of ALTs in the workplace: Discussion summary. Retrieved from http://ajet.net/2013/01/24/winter-2012-oe-utilisationof-alts-in-the-workplace-discussion-summary/

Andrews, S. (2007). Teacher language awareness. Cambridge: Cambridge University Press.

Braine, G. (2010). Nonnative speaker English teachers: Research, pedagogy, and professional growth. New York: Routledge.

Breckenridge, Y., \& Erling, E. (2011). The native speaker English teacher and the politics of globalization in Japan. In P. Seargeant (Ed.), English in Japan in an era of globalization (pp. 80-100). Basingstoke, UK: Palgrave Macmillan.

Browne, C., \& Evans, B. (1994). The ALT as cultural informant: A catalyst for developing students' communicative competence. In M. Wada \& A. Cominos (Eds.), Studies in team teaching (pp. 17-28). Tokyo: Kenkyusha. 
Brumby, S., \& Wada, M. (1992). Team teaching. New York: Longman.

Carless, D. (2006). Good practices in team-teaching in Japan, South Korea and Hong Kong. System, 34, 341-351. doi:10.1016/j.system.2006.02.001

Carless, D., \& Walker, E. (2006). Effective team teaching between local and nativespeaking English teachers. Language and Education, 20, 463-477. doi:10.2167/ le627.0

Cohen, A., \& Ishihara, N. (2013). Pragmatics. In B. Tomlinson (Ed.), Applied linguistics and materials development (pp. 113-126). London: Bloomsbury.

Council for Local Authorities on International Relations (CLAIR). (2012). ALT Handbook. Tokyo: Author.

Crooks, A. (2001). Professional development and the JET Programme: Insights and solutions based on the Sendai Programme. JALT Journal, 23, 31-46.

Garcia, O., \& Menken, K. (2010). Moving forward: Ten guiding principles for teachers. In K. Menken \& O. Garcia (Eds.), Negotiating language policies in schools: Educators as policymakers (pp. 262-268). New York: Routledge.

Glasgow, G. P. (2012). Implementing language education policy to "conduct classes in English" in Japanese senior high schools. In N. Sonda \& A. Stewart (Eds.), JALT2011 Conference Proceedings (pp. 399-407). Tokyo: JALT.

Gorsuch, G. (2002) Assistant foreign language teachers in Japanese schools: Focus on the hosting of Japanese teachers. JALT Journal, 24, 5-32.

Hall, G., \& Cook, G. (2012). Own-language use in language teaching and learning. Language Teaching, 45, 271-308. doi:10.1017/S0261444812000067

Hashimoto, K. (2013). The construction of the 'native speaker' in Japan's educational policies for TEFL. In S. Houghton \& D. Rivers (Eds.), Native-speakerism in Japan: Intergroup dynamics in foreign language education (pp. 159-168). Bristol, UK: Multilingual Matters.

Hiramatsu, S. (2004). English education reform, local contexts, and teacher's responses: A case study of EFL teaching in a high school in Japan (Doctoral dissertation). Available from ProQuest Dissertations and Theses database. (UMI 3141280)

Hongo, J. (2013, March 25). Abe wants TOEFL to be key exam. The Japan Times Online. Retrieved from http://www.japantimes.co.jp

Houghton, S., \& Rivers, D. (Eds.). (2013). Native-speakerism in Japan: Intergroup dynamics in foreign language education. Bristol, UK: Multilingual Matters.

JET (The Japan Exchange \& Teaching Programme). (2010). Teaching materials collection. Retrieved from http://www.jetprogramme.org/e/current/pubs/materials_collection.html 
Kachi, R., \& Lee, C. (2001, May). A tandem of native and nonnative teachers: Voices from Japanese and American teachers in the EFL classroom in Japan. Paper presented at the 2nd International Conference on Language Teacher Education, Minneapolis, MN.

Kaplan, R., \& Baldauf, R. (2003). Language and language-in-education planning in the Pacific basin. Dordrecht, Netherlands: Kluwer Academic Publishers.

Kennedy, C., \& Tomlinson, B. (2013). Implementing language policy and planning through materials development. In B. Tomlinson (Ed.), Applied linguistics and materials development (pp. 255-268). London: Bloomsbury.

Kikuchi, K., \& Browne, C. (2009). English education policy in Japan: Ideals versus reality. RELC Journal, 40, 172-191. doi:10.1177/0033688209105865

Levine, A. (2011). Code choice in the language classroom. Bristol, UK: Multilingual Matters.

Liddicoat, A. J. (2004). Language policy and methodology. International Journal of English Studies, 4(1), 153-171.

Luk, J., \& Lin, A. (2006). Classroom interactions as cross cultural encounters: Native speakers in EFL lessons. Mahwah, NJ: Erlbaum.

Mahoney, S. (2004). Role controversy among team teachers in the JET Programme. JALT Journal, 26, 223-244.

Martin, P. (2005). Safe language practices in two rural schools in Malaysia: Tensions between policy and practice. In A. M. Y. Lin \& P. Martin (Eds.), Decolonization, globalization: Language-in-education policy and practice (pp. 74-97). Clevedon, UK: Multilingual Matters.

McConnell, D. (2000), Importing diversity: Inside Japan's JET Programme. Berkeley: University of California Press.

McGroarty, M., \& Taguchi, N. (2005). Evaluating the communicativeness of EFL textbooks for Japanese secondary schools. In C. Holten \& J. Froedesen (Eds.), The power of context in language teaching and learning (pp. 211-224). Boston, MA: Heinle \& Heinle.

McKenzie, R. (2013). Changing perceptions? A variationist sociolinguistic perspective on native speaker ideologies and standard English in Japan. In S. Houghton \& D. Rivers (Eds.), Native-speakerism in Japan: Intergroup dynamics in foreign language education (pp. 219-230). Bristol, UK: Multilingual Matters.

Medgyes, P. (1999). The nonnative teacher. Munich, Germany: Max Hueber Verlag.

Menken, K. (2008). English learners left behind: Standardized testing as language policy. Clevedon, UK: Multilingual Matters. 
Mie, A. (2013, April 24). LDP plans expansion of JET Programme. The Japan Times Online. Retrieved from http://www.japantimes.co.jp

Ministry of Education, Culture, Sports, Science and Technology (MEXT). (2002). Handbook for Team Teaching. Tokyo: MEXT.

Ministry of Education, Culture, Sports, Science and Technology (MEXT). (2010). Kotogakko gakushu shido yoryo kaisetsu. [Explanation of the senior high school curriculum guidelines. Foreign language and English version]. Retrieved from http://www.mext.go.jp/component/a_menu/education/micro_detail/_icsFiles/afieldfile/2010/01/29/1282000_9.pdf

Ministry of Education, Culture, Sports, Science and Technology (MEXT). (2011a). Kotogakko gakushu shido yoryo [The Course of Study for Foreign Languages-Upper secondary school]. Retrieved from http://www.mext.go.jp/a_menu/shotou/ new-cs/youryou/eiyaku/_icsFiles/afieldfile/2011/04/11/1298353_9.pdf.

Ministry of Education, Culture, Sports, Science and Technology (MEXT). (2011b). Five proposals and specific measures for developing proficiency in English for international communication. Retrieved from http://www.mext.go.jp/component/ english/_icsFiles/afieldfile/2012/07/09/1319707_1.pdf

Miura, S. (2010). Prospective Japanese English teachers' perceptions of using L2 in high school instruction. The Tsuru University Review, 72, 1-17.

Miyazato, K. (2006). Role and power sharing between native and non-native EFL teachers: Three cases of team teaching in Japanese senior high schools (Unpublished doctoral dissertation). Temple University Japan.

Phillipson, R. (1992). Linguistic imperialism. Oxford: Oxford University Press.

Sakui, K. (2004). Wearing two pairs of shoes: Language teaching in Japan. ELT Journal, 58, 155-168. doi:10.1093/elt/58.2.155

Shohamy, E. (2006). Language policy: Hidden agendas \& new approaches. New York: Routledge.

Smiley, J., \& Masui, M, (2008). Materials in Japan: Coexisting traditions. In B. Tomlinson (Ed.), English language learning materials: A critical review (pp. 72-85). London: Continuum.

Tahira, M. (2012). Behind MEXT's new course of study guidelines. The Language Teacher, 36(3), 3-8.

Tajino, A., \& Walker, L. (1998). Perspectives on team teaching by students and teachers: Exploring foundations for team learning. Language, Culture and Curriculum, 11, 113-131. doi:10.1080/07908319808666544

Tollefson, J., \& Tsui, A. (Eds.). (2004). Medium-of-instruction policies: Which agenda? Whose agenda? Mahwah, NJ: Erlbaum. 
Turnbull, M., \& Dailey-O'Cain. (Eds.). (2009). First language use in second and foreign language learning. Clevedon, UK: Multilingual Matters.

Underwood, P. (2012). Teacher beliefs and intentions regarding the instruction of English grammar under national curriculum reforms: A theory of planned behavior perspective. Teaching and Teacher Education, 28, 911-925.

Voci-Reed, E. (1994). Stress factors in the team teaching relationship. In M. Wada \& A. Cominos (Eds.), Studies in team teaching (pp. 61-71). Tokyo: Kenkyusha.

Wada, M. (1994). Team teaching and the revised course of study. In M. Wada \& A. Cominos (Eds.), Studies in team teaching (pp. 7-16). Tokyo: Kenkyusha.

Wada, M., \& Cominos. A. (Eds.). (1994). Studies in team teaching. Tokyo: Kenkyusha.

Yamada, H., \& Hristoskova, G. (2011). Teaching and learning English in English in Japanese senior high schools: Teachers' and students' perceptions. Journal of Fukui-Ken Eigo Kenkyu-Kai, 69, 3-33. 